\title{
Plasma Obestatin Levels in Normal Weight, Obese and Anorectic Women
}

\author{
H. ZAMRAZILOVÁ ${ }^{1}$, V. HAINER ${ }^{1}$, D. SEDLÁČKOVÁ ${ }^{1}$, H. PAPEŽOVÁ ${ }^{2}$, \\ M. KUNEŠOVÁ ${ }^{1}$, F. BELLISLE ${ }^{3}$, M. HILL ${ }^{1}$, J. NEDVÍDKOVÁ ${ }^{1}$ \\ ${ }^{1}$ Institute of Endocrinology and ${ }^{2}$ Eating Disorders Centre, Department of Psychiatry, First Faculty \\ of Medicine, Charles University, Prague, Czech Republic, ${ }^{3}$ INSERM U557, CRNH U1125, Id \\ France, Unité de Recherche en Epidémiologie Nutritionnelle, Bobigny, France
}

Received November 12, 2007

Accepted January 28, 2008

On-line February 13, 2008

\begin{abstract}
Summary
Obestatin is a recently discovered peptide produced in the stomach, which was originally described to suppress food intake and decrease body weight in experimental animals. We investigated fasting plasma obestatin levels in normal weight, obese and anorectic women and associations of plasma obestatin levels with anthropometric and hormonal parameters. Hormonal (obestatin, ghrelin, leptin, insulin) and anthropometric parameters and body composition were examined in 15 normal weight, 21 obese and 15 anorectic women. Fasting obestatin levels were significantly lower in obese than in normal weight and anorectic women, whereas ghrelin to obestatin ratio was increased in anorectic women. Compared to leptin, only minor differences in plasma obestatin levels were observed in women who greatly differed in the amount of fat stores. However, a negative correlation of fasting obestatin level with body fat indexes might suggest a certain role of obestatin in the regulation of energy homeostasis. A significant relationship between plasma obestatin and ghrelin levels, independent of anthropometric parameters, supports simultaneous secretion of both hormones from the common precursor. Lower plasma obestatin levels in obese women compared to normal weight and anorectic women as well as increased ghrelin to obestatin ratio in anorectic women might play a role in body weight regulation in these pathologies.
\end{abstract}

\section{Key words}

Obestatin • Obesity • Anorexia nervosa • Anthropometric indexes - Body fat

\section{Corresponding author}

Vojtěch Hainer, Institute of Endocrinology, Národní třída 8, 11694 Prague 1, Czech Republic. E-mail: vhainer@endo.cz

\section{Introduction}

A new peptide has recently been described and named obestatin by Zhang et al. (2005). Similarly to ghrelin, this 23-amino acid peptide is produced in the stomach from the same precursor - preproghrelin. In contrast to ghrelin, which acts as an appetite stimulant (Wren et al. 2001), treatment of rodents with obestatin supresses food intake (Zhang et al. 2005, Bresciani et al. 2006, Green et al. 2007, Lagaud et al. 2007, Zhang et al. 2007), inhibits jejunal contractions and decreases body weight (Zhang et al. 2005, Bresciani et al. 2006). Recently, several studies have infirmed the inhibitory effects of obestatin on food intake and gastrointestinal motility and did not support the concept that obestatin is a physiological opponent of ghrelin (Gourcerol et al. 2006, De Smet et al. 2007, Holst et al. 2007, Tremblay et al. 2007). Gourcerol and Taché (2007) summarized experimental evidence that obestatin does not influence food intake and gastrointestinal motility and does not represent the cognate ligand for the orphan GPR-39 receptor. These researchers proposed to rename obestatin as ghrelin-associated peptide. In addition, a recent study concerned to characterisation of proghrelin peptides in human plasma and their distribution in mammalian tissues found no obestatin immunoreactivity in human and rat plasma and rat stomach (Bang et al. 2007).

Obese subjects exhibit significantly lower ghrelin levels than healthy normal weight individuals and these levels increase in response to weight loss (Tschop et al. 2001, Cummings et al. 2002). In contrast, patients 
with anorexia nervosa (AN) have elevated plasma ghrelin levels (Otto et al. 2001, Nedvídková et al. 2003) which decline with body weight gain (Otto et al. 2001). Only a few studies on obestatin levels in human obesity have been published. Decreased obestatin levels were reported in morbidly obese subjects referred to bariatric surgery (Haider et al. 2007). Guo et al. (2007) described an elevated ratio of circulating preprandial ghrelin to obestatin ratio in human obesity.

The first aim of our study was to compare obestatin levels in healthy normal weight women (NW) and in female patients with obesity and AN. The second aim of our study was to reveal associations of obestatin levels with ghrelin, leptin and insulin levels. The third aim of the study was to find out correlations of plasma obestatin and ghrelin with body composition and body fat distribution indexes

\section{Methods}

\section{Subjects}

Study was performed in accordance with the Declaration of Helsinki and was approved by the Ethics Committee of the Institute of Endocrinology in Prague. Before the study, each participant signed an informed consent form. Fifteen normal weight women (BMI: $21.6 \pm 0.4 \mathrm{~kg} / \mathrm{m}^{2}$, range $19.7-24.9 \mathrm{~kg} / \mathrm{m}^{2}$; age: $34.7 \pm 1.7$ years, range 24-45 years), 21 women with grade 2 or 3 obesity (BMI: $39.4 \pm 1.2 \mathrm{~kg} / \mathrm{m}^{2}$, range $35.3-3.8 \mathrm{~kg} / \mathrm{m}^{2}$; age: $32.5 \pm 1.1$ years, range $24-45$ years), and 15 women with restrictive type of $\mathrm{AN}$ (BMI: $14.9 \pm 0.3 \mathrm{~kg} / \mathrm{m}^{2}$, range 11.9$17.4 \mathrm{~kg} / \mathrm{m}^{2}$; age: $23.7 \pm 0.9$ years, range $18-29$ years) were enrolled in this study. Healthy NW and obese women were studied in the follicular phase of the regular menstrual cycle. AN patients were diagnosed according to the $4^{\text {th }}$ edition of the Diagnostic and Statistical Manual of Mental Disorders (American Psychiatric Association, 1994) and were examined after two weeks of in-patient stay in the Department of Psychiatry. AN patients were amenorrhoeic. Subjects with endocrine disorders and type 2 diabetes were excluded from the study. The participants did not take any medication susceptible to affect body weight. Five obese patients with hypertension were treated with angiotensin converting enzyme inhibitors.

Blood tests conducted before initiation of the study confirmed normal values for blood count, fasting blood glucose, and liver and renal function. Participants were recommended to avoid vigorous physical activity during the 14-h period before blood sampling. All subjects consumed a standardized dinner at $6 \mathrm{pm}$ under supervision, and were then asked to fast overnight. Reported duration of sleep in the night preceding blood sampling was comparable in all studied subjects. Subjects were admitted to the Institute of Endocrinology at $7 \mathrm{am}$. After physical and ECG examinations, blood samples were collected into chilled tubes containing $\mathrm{Na}_{2}$ EDTA and antilysin. Plasma was immediately separated by centrifugation at $4{ }^{\circ} \mathrm{C}$ and stored at $-80{ }^{\circ} \mathrm{C}$ until being assayed.

After blood withdrawal, anthropometric measurements were carried out according to WHO recommendations (WHO 1995). Body composition was assessed using whole body densitometry (Hologic QDR2000). Fat mass (FM \%), lean body mass (LBM \%) and trunk fat $(\mathrm{TF} \mathrm{kg})$ were determined.

\section{Hormonal assays}

Plasma obestatin immunoreactivity was measured with a commercial RIA kit (Phoenix Pharmaceuticals Inc., Belmont, CA, U.S.A.), the intraand interassay variability was $5.0 \%$ and $14.2 \%$, respectively. The same protocol was used in other clinical studies on obestatin which have been published before (Guo et al. 2007, Haider et al. 2007, Park et al. 2007, Qi et al. 2007). Total plasma ghrelin and leptin were determined using commercially available RIA kits (Linco Research, Inc., St. Charles, Missouri, U.S.A.), plasma insulin levels using commercial RIA kits of Immunotech, Inc. (Prague, Czech Republic).

\section{Statistical analysis}

Data are expressed as means \pm SEM. Differences between age-adjusted variables were evaluated by an analysis of variance (ANOVA). Spearman correlations were computed. Correlations of obestatin with anthropometric and hormonal characteristics in the whole cohort were adjusted for age, and for BMI and waist circumference respectively. The relationship of waist circumference with obestatin level was evaluated by both Spearman's and Pearson's correlations. The power transformations were completed to attain Gaussian data distribution and a constant variance. The points outside of the $95 \%$ confidence ellipsoid (outliers, $n=3$ ) were not included in the correlation analysis.

\section{Results}

The anthropometric and hormonal data of the 
subjects are reported in Table 1. BMI, body weight, waist circumference, fat mass and trunk fat were higher in obese and lower in AN patients in comparison with NW subjects. Plasma leptin and insulin levels were elevated in obese and reduced in AN patients compared with NW subjects. Plasma ghrelin levels were lower in obese and higher in AN patients. Plasma obestatin levels were lower in obese women compared with NW subjects and with AN patients. Ghrelin to obestatin ratio was significantly

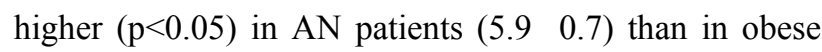
and NW women. This ratio in obese patients $\left(\begin{array}{ll}4.1 & 0.3\end{array}\right)$ did not significantly differ from NW women $\left(\begin{array}{ll}3.6 & 0.2\end{array}\right)$. The decrease in obestatin levels in obese $(25 \%)$ and the lack of change in obestatin levels in AN women contrasts with leptin levels which exhibited several fold changes in obese (3.7 fold increase) and AN (6.2 fold decrease) women. Similarly, ghrelin increases by 1.8 fold in AN compared with NW subjects while there were no significant changes in obestatin levels. In obese patients, obestatin levels decreases by $25 \%$ while changes in ghrelin levels $(-19 \%)$ did not reach statistical significance. Spearman's correlations of plasma obestatin with anthropometric and hormonal characteristics are shown in Table 2. In NW women, significant negative correlations of body weight, waist circumference, body fat $(\%)$, and truncal fat $(\mathrm{kg})$ with the plasma obestatin level were demonstrated whereas LBM correlated positively with obestatin. A significant negative correlation of obestatin with BMI was shown in AN patients. The negative associations of body fat indexes and positive association of LBM with plasma obestatin was shown in the whole cohort after adjustment for age. Figure 1 illustrates a significant negative correlation between waist circumference and obestatin in the whole population (Pearson's correlation after power transformation of both variables: $r=-0.736, p<0.001$ ). A significant positive relationship between obestatin and ghrelin was observed in the obese group $(\mathrm{r}=0.587$, $\mathrm{p}=0.002$ ) and a correlation of borderline significance between these two hormones was revealed in NW women $(\mathrm{r}=0.500, \mathrm{p}=0.058)$. A significant relation of plasma obestatin to plasma leptin $(\mathrm{r}=-0.514, \mathrm{p}=0.05)$ was revealed in NW women, whereas only in obese patients plasma obestatin correlated with insulin $(\mathrm{r}=-0.457$, $\mathrm{p}=0.037$ ). If the data were adjusted for BMI, waist circumference and age in the whole cohort, only correlation of obestatin with ghrelin remained significant, whereas significance disappeared for other hormonal indexes.

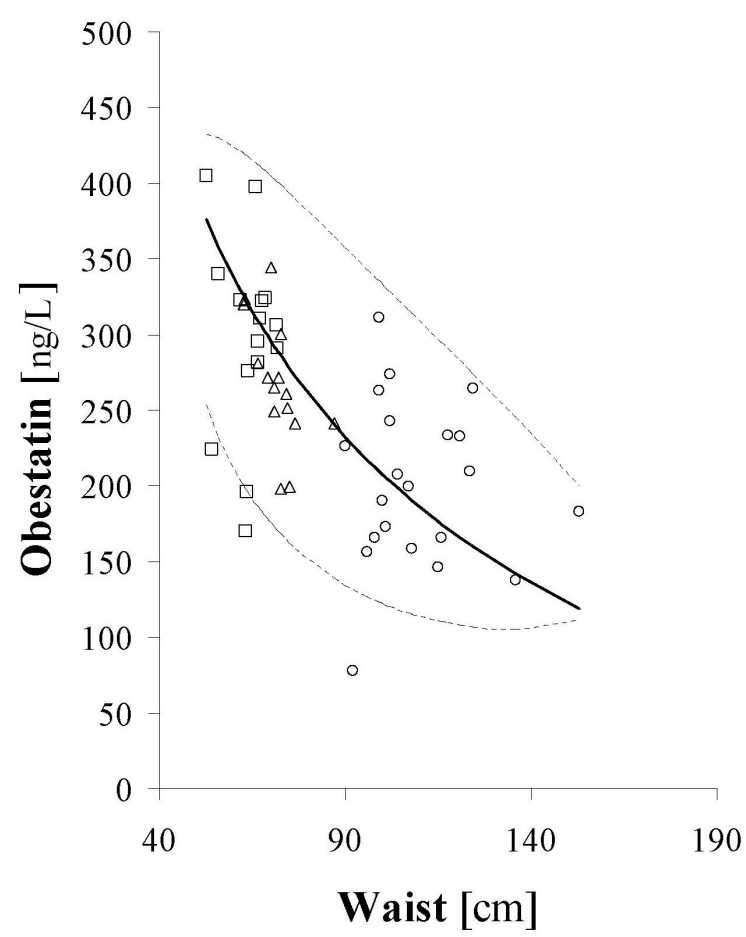

Fig. 1. Relationship between waist circumference and obestatin serum levels for the groups of anorexic women (squares, $n=15$ ), women with normal body weight (triangles, $n=15$ ), and obese women (circles, $n=21$ ). The full and dotted curves represent principal axis and $95 \%$ confidence ellipsoid, respectively as were calculated from the data after power transformations of both variables and re-transformed to the original scale. The power transformations were completed to attain Gaussian data distribution and a constant variance. The point outside of the $95 \%$ confidence ellipsoid (outliers, $n=3$ ) were not included in the correlation analysis. Spearman's correlation: $r=-0.716, p<0.001$ $(n=48)$. Pearson's correlation (after power transformations of both variables): $r=-0.736, p<0.001(n=48)$.

\section{Discussion}

Our study compared fasting plasma obestatin levels in healthy NW women, female patients with obesity and AN. Associations of plasma obestatin levels with selected anthropometric and hormonal indexes were also investigated.

Lower plasma obestatin levels were found in obese subjects compared with NW women and AN patients. These findings agree partly with the study by Guo et al. (2007), in which preprandial obestatin levels were lower in obese men and women. In contrast with our results that study found the higher ghrelin to obestatin ratio in the obese group (Guo et al. 2007). Lower obestatin levels in comparison with NW controls were also reported in severely obese subjects referred to bariatric surgery (Haider et al. 2007). We failed to reveal any significant differences in obestatin levels between 
Table 1. Anthropometric and hormonal characteristics of participants

\begin{tabular}{|c|c|c|c|}
\hline Variable & $\begin{array}{c}\text { NW } \\
(n=15)\end{array}$ & $\begin{array}{c}\text { Obese } \\
(n=21)\end{array}$ & $\begin{array}{c}A N \\
(n=15)\end{array}$ \\
\hline Age (years) & $34.7 \pm 1.7$ & $32.5 \pm 1.1$ & $23.7 \pm 0.9^{a b}$ \\
\hline$B M I\left(\mathrm{~kg} / \mathrm{m}^{2}\right)$ & $21.6 \pm 0.4$ & $39.4 \pm 1.2^{a}$ & $14.9 \pm 0.3^{a b}$ \\
\hline$B W(\mathrm{~kg})$ & $60.1 \pm 1.5$ & $108.9 \pm 4.2^{a}$ & $41.2 \pm 1.3^{a b}$ \\
\hline Waist (cm) & $72.8 \pm 1.5$ & $109.7 \pm 3.4^{a}$ & $64.7 \pm 1.3^{a b}$ \\
\hline$F M(\%)$ & $32.5 \pm 1.2$ & $53.6 \pm 1.1^{a}$ & $11.6 \pm 1.3^{a b}$ \\
\hline$L B M(\%)$ & $66.8 \pm 4.5$ & $45.8 \pm 1.6^{a}$ & $87,6 \pm 1.1^{a b}$ \\
\hline$T F(k g)$ & $6.7 \pm 0.7$ & $29.5 \pm 1.4^{a}$ & $0.8 \pm 0.2^{a b}$ \\
\hline Obestatin (ng/l) & $267.9 \pm 10.8$ & $200.9 \pm 11.9^{a}$ & $297.5 \pm 16.7^{b}$ \\
\hline Total ghrelin (ng/l) & $964.9 \pm 59.9$ & $781.8 \pm 38.6$ & $1732.9 \pm 236.3^{a b}$ \\
\hline Leptin $(\mu g / l)$ & $14.3 \pm 1.7$ & $52.7 \pm 5.6^{a}$ & $2.3 \pm 0.3^{a b}$ \\
\hline Insulin $(m U / l)$ & $6.7 \pm 0.7$ & $14.0 \pm 1.8^{a}$ & $3.6 \pm 0.7^{a b}$ \\
\hline
\end{tabular}

Data are expressed as mean \pm SEM. ${ }^{a} P<0.05$ Obese/AN $v s . N W ;{ }^{b} P<0.05$ AN vs. Obese; AN - women with anorexia nervosa; BMI - body mass index; BW - body weight; FM - fat mass; LBM - lean body mass; NW - normal weight women; TF - trunk fat.

Table 2. Spearman's correlations between obestatin and selected anthropometric, body composition and hormonal characteristics in normal weight (NW), obese and anorectic (AN) women and in all subjects with adjusted data (ALL). Correlations between obestatin and anthropometric variables were adjusted for age $\left({ }^{a}\right)$ and correlations between obestatin and hormonal characteristics are shown after adjustment for age, BMI and waist circumference $\left({ }^{\text {abw }}\right)$

\begin{tabular}{|c|c|c|c|c|c|}
\hline Variable & & $\begin{array}{c}\text { NW } \\
(n=15)\end{array}$ & $\begin{array}{l}\text { Obese } \\
(n=21)\end{array}$ & $\begin{array}{c}\mathrm{AN} \\
(n=15)\end{array}$ & $\begin{array}{c}\text { ALL } \\
(n=51)\end{array}$ \\
\hline$B M I$ & $\mathrm{r}$ & -0.257 & -0.160 & -0.567 & $-0.646^{\mathrm{a}}$ \\
\hline$\left(\mathrm{kg} / \mathrm{m}^{2}\right)$ & $\mathrm{p}$ & 0.356 & 0.489 & 0.028 & $<0.001$ \\
\hline$B W$ & $\mathrm{r}$ & -0.711 & -0.206 & -0.247 & $-0.641^{\mathrm{a}}$ \\
\hline$(\mathrm{kg})$ & $\mathrm{p}$ & 0.003 & 0.371 & 0.376 & $<0.001$ \\
\hline Waist & $\mathrm{r}$ & -0.769 & 0.014 & -0.043 & $-0.603^{a}$ \\
\hline$(\mathrm{cm})$ & $\mathrm{p}$ & 0.001 & 0.951 & 0.907 & $<0.001$ \\
\hline$F M$ & $\mathrm{r}$ & -0.525 & -0.169 & 0.150 & $-0.498^{\mathrm{a}}$ \\
\hline$(\%)$ & $\mathrm{p}$ & 0.044 & 0.563 & 0.700 & 0.002 \\
\hline$L B M$ & $\mathrm{r}$ & 0.532 & 0.187 & -0.517 & $0.476^{\mathrm{a}}$ \\
\hline$(\%)$ & $\mathrm{p}$ & 0.041 & 0.523 & 0.154 & 0.003 \\
\hline$T F$ & $\mathrm{r}$ & -0.586 & -0.024 & -0.250 & $-0.525^{\mathrm{a}}$ \\
\hline$(\mathrm{kg})$ & $\mathrm{p}$ & 0.021 & 0.935 & 0.516 & 0.001 \\
\hline Total ghrelin & $\mathrm{r}$ & 0.500 & 0.587 & 0.364 & $0.494^{\mathrm{abw}}$ \\
\hline$(n g / l)$ & $\mathrm{p}$ & 0.058 & 0.002 & 0.182 & $<0.001$ \\
\hline Leptin & $\mathrm{r}$ & -0.514 & 0.257 & -0.231 & $0.164^{\mathrm{abw}}$ \\
\hline$(\mu g / l)$ & $\mathrm{p}$ & 0.050 & 0.375 & 0.408 & 0.227 \\
\hline Insulin & $\mathrm{r}$ & -0.207 & -0.457 & 0.022 & $-0.146^{\mathrm{abw}}$ \\
\hline$(m U / l)$ & $\mathrm{p}$ & 0.459 & 0.037 & 0.943 & 0.261 \\
\hline
\end{tabular}

$\mathrm{r}=$ correlation coefficient, $\mathrm{p}=P$ value, $^{\mathrm{a}}=$ adjusted for age, ${ }^{\text {abw }}=$ adjusted for age, BMI and waist circumference, BMI - body mass index; BW - body weight; FM - fat mass; LBM - lean body mass; TF - trunk fat. 
AN and NW women. However, the higher ghrelin to obestatin ratio in AN might reflect a long-term reduction in energy intake which could contribute to susceptibility of AN women to bulimic episodes. The differences in anthropometric and hormonal parameters between anorectic subjects and the other groups remained significant after adjustment for age and so the effect is not age related. Minor differences in plasma obestatin levels between women who greatly differ in energy balance and amount of fat stores infirm major role of this novel hormone in energy homeostasis. Nevertheless, an observed significant negative correlation of fasting obestatin level with total and truncal body fat indexes as well as with plasma leptin level together with the positive correlation between obestatin and LBM might suggest a role of obestatin in body weight regulation under physiological conditions. A lack of significant correlation between obestatin and BMI in normal weight subjects might reflect discordant associations of obestatin with fat mass and LBM and the fact that BMI does not distinguish fat mass from LBM. No relationship between baseline obestatin levels and the BMI SDS was recently reported in obese children (Park et al. 2007). The absence of correlation between plasma obestatin and anthropometric and body composition data in our obese group could be related to suppressed fasting obestatin levels in obesity which might be a marker of disrupted regulation of fat stores. A negative correlation between plasma obestatin levels and BMI in AN may suggest a contribution of obestatin in determining body weight in this pathology. A lack of correlations of body composition paramaters with obestatin in women with AN is partly due to the narrow range of values of FM and LBM, which are both low due to nutritional deficiency.

A significant simultaneous increase of both plasma ghrelin and obestatin levels was demonstrated with weight loss in morbidly obese patients 6 months after gastric banding (Haider et al. 2007). The positive correlation between plasma ghrelin and obestatin revealed both in the group of obese women and in the whole cohort supports a hypothesis of simultaneous secretion of these two hormones from the common precursor. This might result in a mutual balance in the appetite regulation activities of ghrelin and obestatin. Correlation of obestatin with ghrelin remained significant when the data were controlled for age, BMI and waist circumference. This means that an association of obestatin with ghrelin exists independently of anthropometric indexes. Recent experimental studies brought discordant results concerning the role of obestatin in regulation of energy homeostasis. Some of the studies (Bresciani et al. 2006, Green et al. 2007, Lagaud et al. 2007, Zhang et al. 2007) partly confirmed the original findings of Zhang et al. (2005), but others failed to confirm the original data (Gourcerol et al. 2006, De Smet et al. 2007, Gourcerol and Taché 2007, Holst et al. 2007, Tremblay et al. 2007).

In agreement with previous reports (Otto et al. 2001, Tschop et al. 2001, Cummings et al. 2002, Nedvídková et al. 2003, Rosická et al. 2003), in our study plasma ghrelin levels were significantly higher in AN patients and lower in obese patients in comparison with NW women.

An inverse relationship between obestatin and insulin levels was revealed in our obese group. Only a few clinical data are available about the association between plasma obestatin and insulin levels. Park et al. (2007) measured plasma obestatin, ghrelin and insulin levels during a glucose tolerance test and evaluated the area under the curve (AUC) after a glucose challenge in obese children. A negative correlation of borderline significance between the AUC of obestatin and insulin was shown in control group of obese children $(\mathrm{r}=-0.331$, $\mathrm{p}=0.09$ ). According to Qi et al. (2007) decreasing concentrations of obestatin are independently and significantly associated with impaired glucose regulation and type 2 diabetes. More studies are required to evaluate a potential role of insulin in obestatin regulation comparable to that demonstrated in ghrelin regulation.

In conclusion, we found that obese women have lower levels of obestatin compared to NW and AN women whereas ghrelin to obestatin ratio was increased in AN women. The observed significant relationship of fasting obestatin level with body composition measures found in NW women and in the whole cohort was absent in obese women probably as a consequence of suppressed secretion of obestatin in obesity. However, the potential physiological role of obestatin in body weight regulation requires further elucidation.

$\begin{array}{ll}\text { Abbreviations } \\ \text { AN } & \text { anorexia nervosa } \\ \text { AUC } & \text { area under the curve } \\ \text { BMI } & \text { body mass index } \\ \text { BW } & \text { body weight } \\ \text { FM } & \text { fat mass } \\ \text { LBM } & \text { lean body mass } \\ \text { NW } & \text { normal weight } \\ \text { TF } & \text { trunk fat }\end{array}$




\section{Conflict of Interest}

There is no conflict of interest.

\section{Acknowledgements}

This study was supported by grant NR 7800-4 provided by the Czech Ministry of Health and by Research Aim MSM0021620816.

\section{References}

BANG AS, SOULE SG, YANDLE TG, RICHARDS AM, PEMBERTON CJ: Characterisation of proghrelin peptides in mammalian tissue and plasma. J Endocrinol 192: 313-323, 2007.

BRESCIANI E, RAPETTI D, DONA F, BULGARELLI I, TAMIAZZO L, LOCATELLI V, TORSELLO A: Obestatin inhibits feeding but does not modulate GH and corticosteroid secretion in the rat. $J$ Endocrinol Invest 29: RC16-RC18, 2006.

CUMMINGS DE, WEIGLE DS, FRAYO RS, BREEN PA, MA MK, DELLINGER EP, PURNELL JQ: Plasma ghrelin levels after diet-induced weight loss or gastric bypass surgery. $N$ Engl J Med 346: 1623-1630, 2002.

DE SMET B, THIJS T, PEETERS TL, DEPOORTERE I: Effect of peripheral obestatin on gastric emptying and intestinal contractility in rodents. Neurogastroenterol Motil 19: 211-217, 2007.

GREEN BD, IRWIN N, FLATT PR: Direct and indirect effects of obestatin peptides on food intake and the regulation of glucose homeostasis and insulin secretion in mice. Peptides 28: 981-987, 2007.

HOLST B, EGEROD KL, SCHILD E, VICKERS SP, CHEETHAM S, GERLACH LO, STORJOHANN L, STIDSEN CE, JONES R, BECK-SICKINGER AG, SCHWARTZ TW: GPR39 signaling is stimulated by zinc ions but not by obestatin. Endocrinology 148: 13-20, 2007.

GOURCEROL G, MILLION M, ADELSON DW, WANG Y, WANG L, RIVIER J, ST-PIERRE DH, TACHE Y: Lack of interaction between peripheral injection of CCK and obestatin in the regulation of gastric satiety signaling in rodents. Peptides 27: 2811-2819, 2006.

GOURCEROL G, TACHÉ Y: Obestatin - a ghrelin-associated peptide that does not hold its promise to suppress food intake and motility. Neurogastroenterol Motil 19: 161-165, 2007.

GUO ZF, ZHENG X, QIN YW, HU JQ, CHEN SP, ZHANG Z: Circulating preprandial ghrelin to obestatin ratio is increased in human obesity. J Clin Endocrinol Metab 92: 1875-1880, 2007.

HAIDER DG, SCHINDLER K, PRAGER G, BOHDJALIAN A, LUGER A, WOLZT M, LUDVIK B: Serum retinolbinding protein-4 is reduced after weight loss in morbidly obese subjects. J Clin Endocrinol Metab 92: 11681171, 2007.

LAGAUD GJ, YOUNG A, ACENA A, MORTON MF, BARRETT TD, SHANKLEY NP: Obestatin reduces food intake and suppresses body weight gain in rodents. Biochem Biophys Res Commun 357: 264-269, 2007.

NEDVÍDKOVÁ J, KRYKORKOVÁ I, BARTÁK V, PAPEŽOVÁ H, GOLD PW, ALESCI S, PACÁK K: Loss of meal-induced decrease in plasma ghrelin levels in patients with anorexia nervosa. $J$ Clin Endocrinol Metab 88: 1678-1682, 2003.

OTTO B, CUNTZ U, FRUEHAUF E, WAWARTA R, FOLWACZNY C, RIEPL RL, HEIMAN ML, LEHNERT P, FICHTER M, TSCHOP M: Weight gain decreases elevated plasma ghrelin concentrations of patients with anorexia nervosa. Eur J Endocrinol 145: 669-673, 2001.

PARK WH, OH YJ, KIM GY, KIM SE, PAIK KH, HAN SJ, KIM AH, CHU SH, KWON EK, KIM SW, JIN DK: Obestatin is not elevated or correlated with insulin in children with Prader-Willi syndrome. J Clin Endocrinol Metab 92: 229-234, 2007.

QI X, LI L, YANG G, LI K, TANG Y, LIOU H, BODEN G: Circulating obestatin levels in normal subjects and in patients with impaired glucose regulation and type 2 diabetes mellitus. Clin Endocrinol (Oxf) 66: 593-597, 2007.

ROSICKÁ M, KRŠEK M, MATOULEK M, JARKOVSKÁ Z, MAREK J, JUSTOVÁ V, LACINOVÁ Z. Serum ghrelin levels in obese patients: the relationship to serum leptin levels and soluble leptin receptors levels. Physiol Res 52: 61-66, 2003. 
TSCHOP M, WEYER C, TATARANNI PA, DEVANARAYAN V, RAVUSSIN E, HEIMAN ML: Circulating ghrelin levels are decreased in human obesity. Diabetes 50: 707-709, 2001.

TREMBLAY F, PERREAULT M, KLAMAN LD, TOBIN JF, SMITH E, GIMENO RE: Normal food intake and body weight in mice lacking the G protein-coupled receptor GPR39. Endocrinology 148: 501-506, 2007.

WHO Expert Committee Physical status: The use and interpretation of anthropometry, pp 452. Geneva: WHO Technical Series Report No. 854, 1995.

WREN AM, SEAL LJ, COHEN MA, BRYNES AE, FROST GS, MURPHY KG, DHILLO WS, GHATEI MA, BLOOM SR: Ghrelin enhances appetite and increases food intake in humans. J Clin Endocrinol Metab 86: 5992-5995, 2001.

ZHANG JV, REN P-G, AVSIAN-KRETCHMER O, LUO CH-W, RAUCH R, KLEIN C, HSUEH AJW: Obestatin, a peptide encoded by the ghrelin gene, opposes ghrelin's effects on food intake. Science 310: 996-999, 2005.

ZHANG JV, KLEIN C, REN PG, KASS S, VER DONCK L, MOECHARS D, HSUEH AJW: Response to comment on „Obestatin, a peptide encoded by the ghrelin gene, opposes ghrelin's effects on food intake“. Science 315: 766, 2007. 